\title{
The presence of elk (Alces alces) in Austria since the upper Pleistocene
}

\author{
Wolfgang NEUNER ${ }^{1} \&$ Christoph SPÖTL ${ }^{2 *}$ \\ 1) Tiroler Landesmuseen, Naturwissenschaftliche Sammlungen, Museumstraße 15, 6020 Innsbruck, Austria; current address: Goethestraße 13, 6020 \\ Innsbruck, Austria \\ 2) Institute of Geology, University of Innsbruck, Innrain 52, 6020 Innsbruck, Austria \\ *) Corresponding author: christoph.spoetl@uibk.ac.at
}

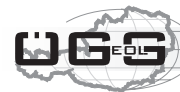

KEYWORDS Elk, Pleistocene, Holocene, radiocarbon dating, Eastern Alps, Austria

\begin{abstract}
This study reports new data on the occurrence of elk remains in the western, mountainous part of Austria and also provides a compilation of all currently known 107 elk finds of the upper Pleistocene to upper Holocene in this country. The altitudinal distribution reveals two maxima for Austria: a lower one at about $400 \mathrm{~m}$ a.s.l., which comprises the alpine foreland, and a second one at about 1600-1800 m a.s.l., reflecting the abundance of vertical caves in the Northern Calcareous Alps at this elevation (animal traps). Vorderkarhöhle in Tyrol is the highest known elk find in Austria (1860 m a.s.l.), interestingly located above the tree line. Although only $11 \%$ of all elk sites in Austria have been radiocarbon-dated, stratigraphic and archaeological constraints allow to assign $90 \%$ of those sites that lack radiometric dating to either the upper Pleistocene (18\%) or the Holocene (72\%). Among the latter, upper Holocene sites dominate (78\%), followed by middle (16\%) and lower Holocene (6\%) sites. The youngest radiocarbon-dated elk find in Austria is from Gaflein Valley (Tyrol, 1285-1359 cal BP), in agreement with data from the Swiss Alps, showing that the elk survived beyond Roman times in the Alps and became extinct before the onset of the Middle Ages.
\end{abstract}

\section{Introduction}

The elk (moose, Alces alces) is the largest living terrestrial mammal in Europe after the European bison, and the largest cervid. It is an holarctic animal whose modern distribution encompasses northern Eurasia from Scandinavia and Poland to Eastern Siberia, northern Mongolia and northern China, Alaska, Canada and the northern United States (Nygrén, 1986). Elks live in forests, prefer wet and swampy environments, are cold-tolerant and can cope with snow heights up to 0.6 m (Nygrén, 1986). Compared to red deer (Cervus elaphus) elks are therefore found in colder and more snow-rich regions (cf. Rosvold et al., 2013).

The elk first appeared during the penultimate glacial period (Nygrén, 1986) but remained a minor component of the upper Pleistocene fauna (Serangeli, 2006). It became rare during the Last Glacial Maximum (LGM) north of the Alps and survived in a woodland or open park tundra south of the margin of the Scandinavian ice sheet (Aaris-Sørensen, 1992). After the LGM elks were among the first large mammals to re-colonise Central Europe (Willms, 1987). Their abundance increased during the following millennia and peaked during the lower Holocene, when elks populated Europe from the Pyrenees to
Denmark and from the Alps to Great Britain (Schmölcke and Zachos, 2005). During the Preboreal they started to vanish from the (south)western part of Europe, including France and Great Britain. During the Atlantic period, elks died out in Denmark and their population thinned in Central Europe. Only relict populations remained in Central Europe during Roman times and they gradually disappeared during early medieval times. Further east, some stocks persisted until the late Middle Ages (Schmölcke and Zachos, 2005).

The purpose of this study was to review the status of elk finds in Austria, to compile a comprehensive database of all finds in this country, and to present new data with a focus on inner-Alpine elk occurrences in western Austria.

\section{The elk in Austria}

Historically speaking, the first discovery of prehistoric elk remains in Austria was made in 1856 at Wildes Loch, a cave on Grebenzen, Styria (cave register no. 2743/1; Schmidt (1859), Aichhorn and Plankensteiner (1875)). This was followed by findings in the area north (Schusterloch, cave register no. 1564/11, Teller (1880)) and east of the Dachstein massif (Mausbendlloch, cave register no. 1548/2; Dimitz (1879)). Over the following decades 
elk remains were discovered in various parts of Austria, but rarely presented in more detail. Exceptions are the publications by Mutschlechner (1959) and Graf (2014) on elk finds in the Karwendel Mountains of Tyrol and in the Kammer Mountains in Styria, respectively. The compilation by Döppes and Rabeder (1997) of the Pleistocene fauna in Austria contains data on ten elk-bearing sites, seven of which are caves.

Bauer and Spitzenberger (2001) gave a concise and authorative overview of prehistoric and recent finds of elk in Austria. They showed that the elk appeared in low abundances in Austria during the upper Pleistocene, disappeared during the LGM, re-appeared during the Late Glacial and lower Holocene, and finally vanished during the early Middle Ages. Bauer and Spitzenberger (2001) provided a map of Holocene elk finds which shows a rather uniform distribution across the country with a density maximum in the Northern Calcareous Alps east of Salzburg. Unfortunately, the locations on this map are not identified and the data, on which this map is based, are not provided in their publication (nor in the electronic appendix). We located and studied the original documents of K. Bauer (deceased 2016) at the Museum of Natural History in Vienna and managed to identify most of the sites shown in Bauer and Spitzenberger (2001). In addition, we compiled the scattered literature, in particular various cave-related and archaeological reports, and added new sites. We focus here on the western part of Austria and provide a set of new radiocarbon ages to augment the very small database of radiometrically dated elk remains (Bauer and Spitzenberger (2001) listed only two radiocarbon dates).
Figure 1 provides an overview map of elk finds in Austria and a comprehensive list of all currently known 107 Austrian localities is provided in Supplementary Table 1. The map reveals the highest density of elk remains in the central and eastern segment of the Northern Calcareous Alps coinciding with the highest density of caves (primarily vertical ones that act as traps) in this part of the Alps (Plan and Oberender, 2016). $46 \%$ of all elk sites in Austria are caves, underscoring the importance of these animal traps for preservation. Scattered elk finds, however, are known from all other parts of the country, from the Alpine foreland to the valleys of the Central Alps.

Mostly isolated antlers were found, with the exception of a few caves where complete skeletons were discovered (e.g., Elchhöhle near Altaussee, Vorderkarhöhle near Scharnitz). Several finds were made during archaeological excavations, but elk bones were never abundant in these sites.

\section{Inneralpine elk sites in western Austria}

The following section focusses on elk finds from the mountainous western part of Austria, primarily the state of Tyrol. Most of these sites were either never published before or reported in local journals only. Their locations are shown in Figure 1. Radiocarbon values are reported both as conventional ages and as calibrated ages (using INTCAL13, 2 sigma range).

\subsection{Spullersee}

This lake is located at $1827 \mathrm{~m}$ a.s.l. in the eastern Lechquellen Mountains. Its sediments yielded the only known elk remain from the state of Vorarlberg. When Spullersee

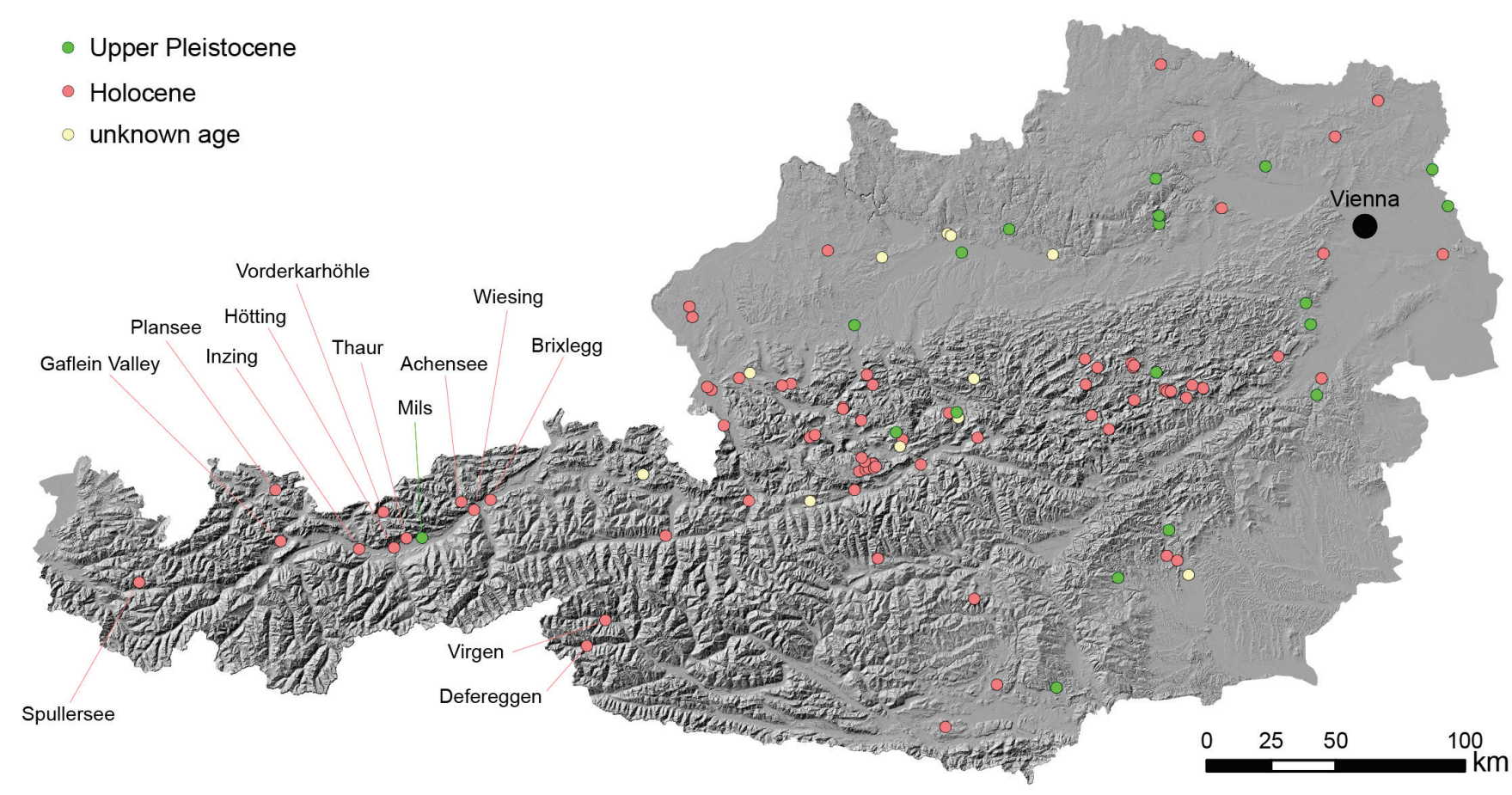

Fig. 1: Digital elevation model of Austria showing the distribution of Holocene and upper Pleistocene elk finds. Sites in western Austria discussed in this study are identified. 
was modified for hydroelectric purpose and its lake level was artificially lowered in 1921, antlers of elk together with antlers of deer, bear bones and logs of conifer trees were found in the deeper layers of the lake mud (Geilhofer, 1926). No further details about the site and its stratigraphy were reported, and the elk antler was sold to an unknown person in Switzerland (pers. comm. by $\mathrm{H}$. Konzett 2004, the son of A. Konzett, who found the specimen in the lake mud).

\subsection{Plansee}

This lake is located in NW Tyrol at an elevation of $976 \mathrm{~m}$ a.s.I. In 1954, elk antlers were found on the shore of the northwestern branch of this lake, known as Kleiner Plansee (Mutschlechner, 1959: 78). Another report states that an incomplete antler was found during dredging work in a layer of loam in about $50 \mathrm{~m}$ water depth (Anonymous, 1954). Several attempts to locate this specimen were unsuccessful.

\subsection{Gaflein Valley}

A fragment of an elk antler was discovered in 1999 in Gaflein Valley west of Nassereith at an elevation of about $1700 \mathrm{~m}$ a.s.l. (Jäger, 2002; Fig. 2). A sample was radiocarbon-dated to $1410 \pm 30$ BP (1285-1359 cal BP).

\subsection{Vorderkarhöhle}

This cave (cave register no. 1254/1) opens at 1860 m NE of Scharnitz on the western end of the main ridge of the Karwendel Mountains. In the entrance part of this cave, which forms a $6 \mathrm{~m}$-deep shaft open to the surface (Pietersteiner and Spötl, 2011), a skeleton of an female elk

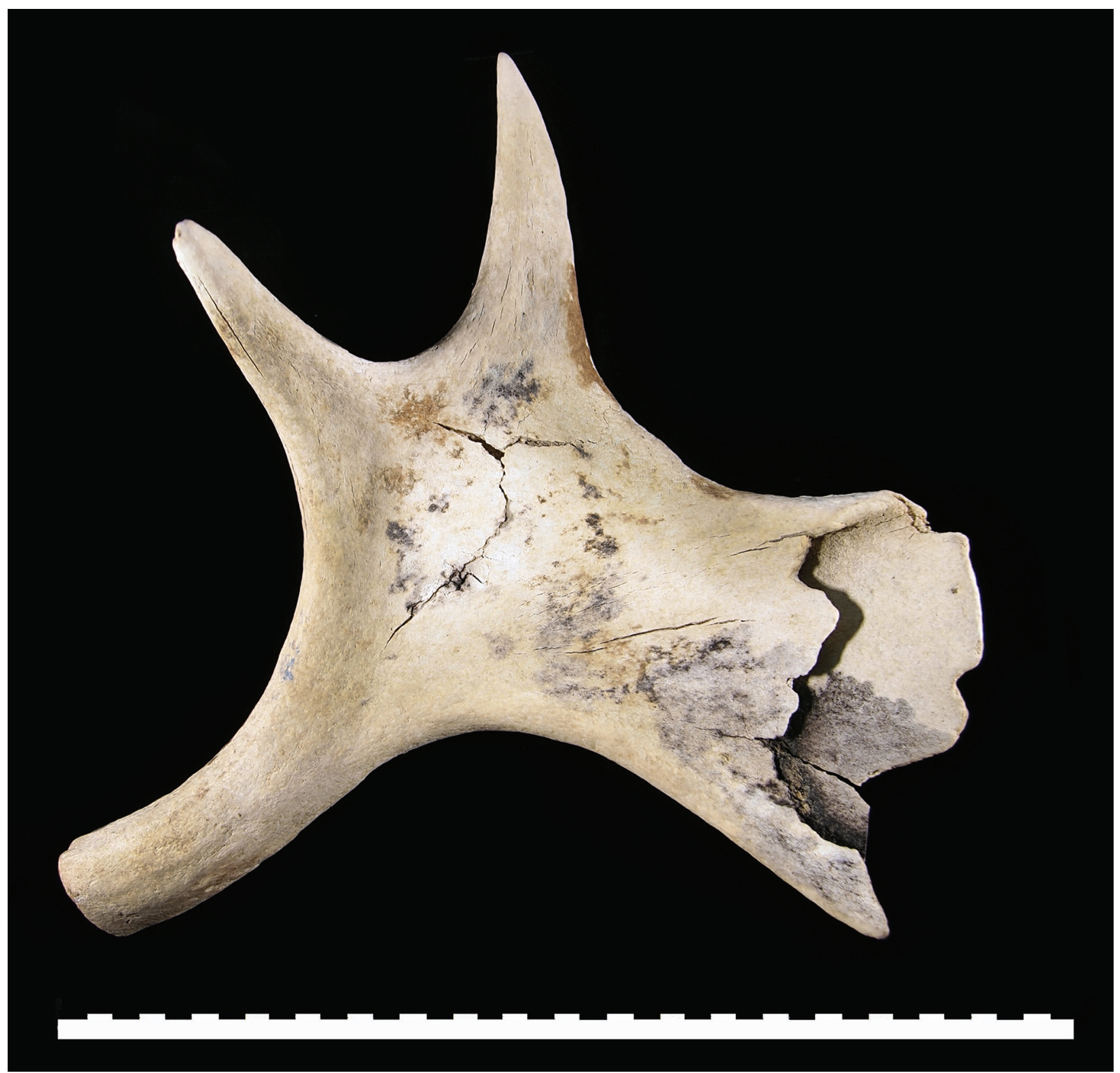

Fig. 2: Antler found in Gaflein Valley and dated to 1285-1359 cal BP. Cm-scale. Photo: S. Heim (TLM) 


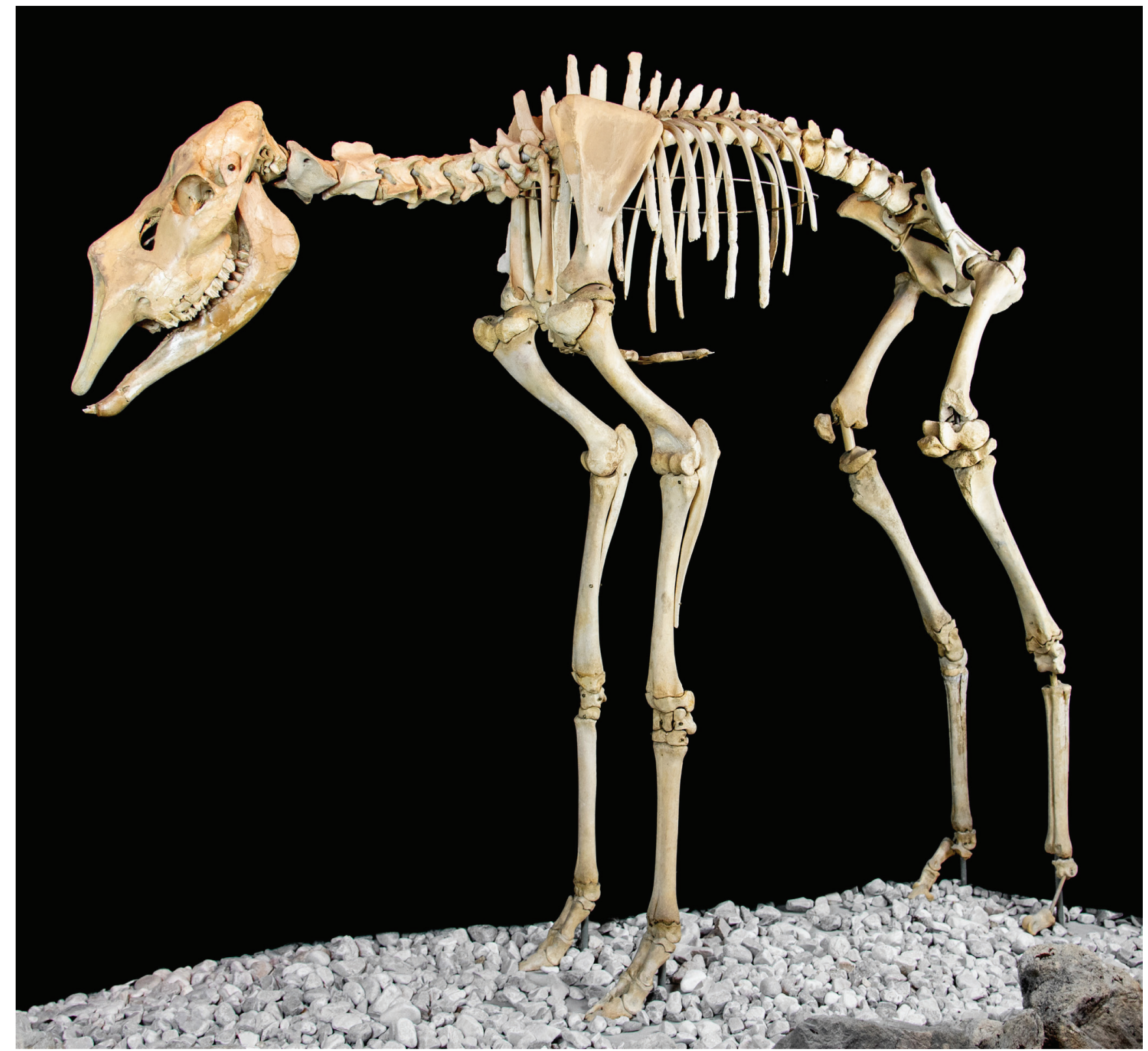

Fig. 3: Reconstructed skeleton of the elk calf from Vorderkarhöhle on display at the Infozentrum Scharnitz. Photo: H. Neuner

calf was found in 1951 (Mutschlechner, 1959; Fig. 3). The frontal part of the skull was shattered, probably related to the fall into the cave, and the skeleton was almost complete. It is the highest-elevation find of an elk skeleton in Austria. A sample was radiocarbon-dated to $2250 \pm 35$ BP (2154-2272 (67.8\%), 2294-2345 (32.2\%) cal BP).

\subsection{Inzing}

In this village on the southern side of the upper Inn Valley, banded clay-rich silts crop out and were mined in a quarry for brick manufacturing until the second half of the 20th century. Paschinger (1950: 58) described the exposure in the former quarry, showing that the silts are sharply overlain by a 2-3 $\mathrm{m}$ thick sliding mass which contained logs of Scots pine up to $1 \mathrm{~m}$ in diameter and a fossil that was described as a "strongly mineralised thighbone". This unit was overlain by $1.5 \mathrm{~m}$ of poorly stratified brown loam and gravel.
The lowermost banded silts are sterile and belong to the upper Pleistocene Baumkirchen Formation (Spötl et al., 2013), while the other two units - because of their lack of (ice-induced) overcompaction and the presence of tree logs - suggest a Late Glacial or Holocene age (Preboreal according to Paschinger, 1950). The thighbone was examined by H. Zapfe (in: Heißel, 1954: 270) and determined as a right metacarpus of Alces cf. alces. This specimen appears to be lost.

\subsection{Thaur}

A small elk bone was identified among many animal bones in an archaeological excavation at Kiechlberg, a small hill at $1024 \mathrm{~m}$ a.s.l. in Thaur some $10 \mathrm{~km}$ ENE of Innsbruck (Töchterle, 2015). The sample yielded a radiocarbon age of $4734 \pm 45 \mathrm{BP}$ (5325-5409 (32.5\%), 5445-5585 $(67.5 \%)$ cal BP), which is consistent with the archaeological context of this find (U. Töchterle, pers. comm. 2018). 
Three more elk remains of upper Holocene age are known from the Inn Valley, found during archaeological excavations. These include Innsbruck (Hötting - e.g., Moser, 1970), Wiesing (Buchberg - Pucher, 1986), and Brixlegg (Mariahilfbergl - Huijsmans and Krauß, 2015). See Supplementary Table 1 for more information.

\subsection{Mils}

A former gravel quarry at Mils near Hall in Tirol exposed a succession of fluvioglacial gravel capped by lodgement till of the LGM (Heißel, 1954; Mayr, 1968; Fliri, 1971). Femur fragments found in the middle part of the gravel section were determined as Alces cf. alces (by $\mathrm{H}$. Zapfe, in: Heißel, 1954). Radiocarbon dates of two specimens yielded $27538 \pm 158$ and $27805 \pm 155$ BP (Spötl et al., 2013; Supplementary Table 1). Here we report a radiocarbon age of a third specimen, a clavicula bone from the same quarry, and presumably from the same layer where the femur bones were recovered (it is not clear whether this bone also belongs to Alces cf. alces). The radiocarbon age overlaps with the published ages (Supplementary Table 1) and confirms the previous age assignment of the Alces cf. alces remains to 31-33 cal ka BP.

\subsection{Achensee}

This largest lake in Tyrol is located between the Karwendel and Rofan Mountains and contains a Late Glacial to Holocene sediment fill overlain by till. Mutschlechner (1959: 78) mentioned that elk antlers were retrieved (possibly fished) from this lake, without providing further information (Fig. 4). One specimen was radiocarbon dated to $4185 \pm 35$ BP (4586-4596 (1.6\%), 4612-4767 (74.4\%), 4783-4839 (24.0\%) cal BP).

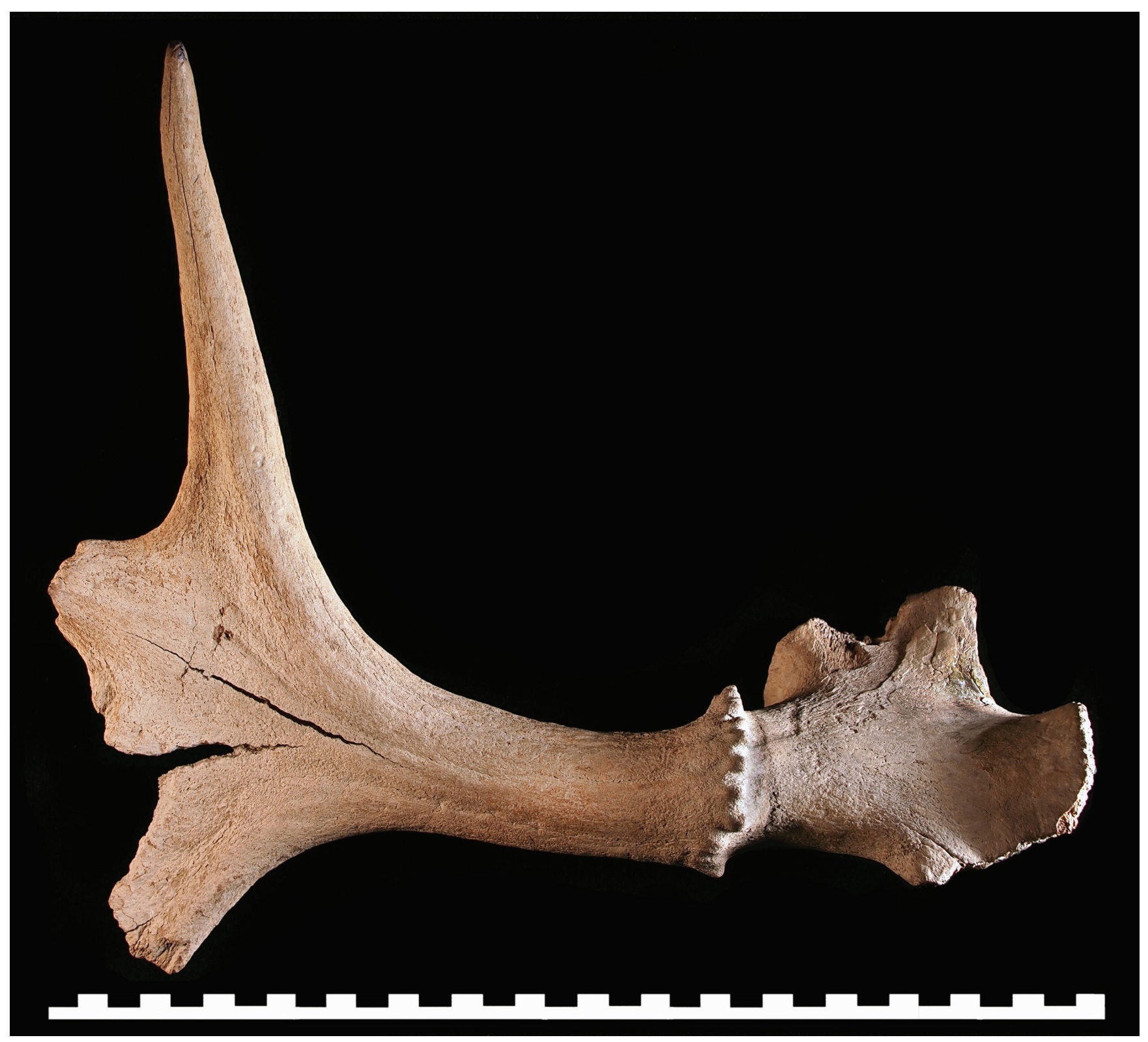

Fig. 4: Antler found in Achensee. Cm-scale. Photo: S. Heim (TLM) 


\subsection{Virgen}

Mutschlechner (1959, S. 78) mentioned that a fragment of an elk antler was found incorporated into the wall of a building in Virgen, Eastern Tyrol. No further information is available and it is unclear whether this specimen still exists.

\subsection{Defereggen}

A similar situation was reported from Defereggen Valley located south of Virgen Valley. There, a fragment of an elk antler (Fig. 5) was found incorporated into the wall of St Leonhard's church east of St Jakob in Defereggen. This specimen was supposedly discovered during excavation work in preparation for the construction of this church in the 15th century (Kollreider, 1953:7-8; Velthuysen, 1961). The church was built on a debris-flow fan which dammed the main local river and resulted in the formation of an episodic lake which later turned into a swampy area. The specimen yielded a radiocarbon age of $5659 \pm 32 \mathrm{BP}$ (6323-6338 (1.5\%), 6341-6371 (4.3\%), 6393-6503 (94.3\%) cal BP).

\section{Discussion}

\subsection{Preservation bias}

$46 \%$ of all sites where elk remains were found in Austria are caves, and the vast majority of them pits, underscoring the importance of such traps for the subfossil mammal record. "Hotspots" include the eastern extension of the Dachstein plateau, known as Kammer Mountains (northwestern part of Styria). Interestingly, its northern part was previously known as "Elendgebirge", whereby "Elen" or "Elend" is an old and obsolete German name for elk (Graf, 2014). A second area of a high density of elk finds is the Tonion, a small and equally strongly karstified massif SE of Mariazell (northeastern part of Styria).

In addition to vertical caves, elk remains were also found in some lake sediments (e.g. in Tyrol), embedded in fluvial gravel (several finds in Linz, Upper Austria) as well as in archaeological excavations.

\subsection{Areal distribution}

As discussed above, the abundance of (vertical) caves in the Northern Calcareous Alps is a major control of the areal distribution of elk finds in Austria. The density of elk finds is significantly lower in the Alpine foreland as well as in the Central Alps (see below).

It is interesting to compare this pattern to Switzerland, for which Chaix and Desse (1981) provided a map of 64 fossil elk finds. The vast majority of the Swiss finds is concentrated on the Swiss Plateau and in the adjacent Jura Mountains. Only a handful of finds are known from the northern part of the Swiss Alps. Elk remains are conspicuously absent in the high Central Alps, including major valleys such as the Rhone Valley. This pattern is consistent with the data shown in Figure 1, although there are a few scattered occurrences of elk finds also in the valleys of the Central Alps of Austria, including the two finds from Eastern Tyrol presented in this study.

\subsection{Altitudinal distribution}

Figure 6 provides an overview of the altitude at which the 107 elk remains were found (and where these animals presumably lived at least seasonally). The bimodal distribution is in contrast to the previous study by Bauer and Spitzenberger (2001) who concluded that elk finds in Austria are evenly distributed across the elevation gradient. Their database comprised 33 sites of Holocene finds only.

The new distribution chart suggests a first maximum at about $400 \mathrm{~m}$ a.s.l. and a second one at about 1600$1800 \mathrm{~m}$ a.s.l. While the latter reflects the abundance of elk finds in karst caves of the Northern Calcareous Alps, which are commonly located at these elevations in the state of Styria, the first maximum mostly comprises finds in the foreland of the Alps, including the Salzburg Basin, the Danube corridor and sites east and south of the Alps (Fig. 1). This lower elevation maximum compares well to Switzerland where the highest density of elk finds also occurs on the Swiss Plateau at approximately 400-500 m a.s.l. (Chaix and Desse, 1981).

The highest known occurrence of elk in Austria is the nearly complete skeleton of a calf found in Vorderkarhöhle which opens at $1860 \mathrm{~m}$ a.s.l. in the Karwendel Mountains. This find is remarkable, because the site is located in a thicket of dwarf pine (Pinus mugo) above the timber line, which lies around $1700 \mathrm{~m}$ a.s.l. in this area. There are no data available for the elevation of the treeline in the Karwendel Mountains some 2200 years before present. Data from Kauner Valley indicate, however, that at that time the treeline in the Central Alps of Tyrol was about $100 \mathrm{~m}$ lower than during the end of the 20th century (Nicolussi et al., 2005). This suggests that the elk calf likely went some $250 \mathrm{~m}$ above the local timberline and eventually died there.

The second highest find of elk remains in Austria is from Spullersee at about $1827 \mathrm{~m}$ a.s.l. Currently the treeline in this part of the Lechquellen Mountains straddles between about 1700 and $1800 \mathrm{~m}$ a.s.l. Finds of elk just above $1800 \mathrm{~m}$ a.s.l. were also reported from the Kammer Mountains (NW Styria, Doppelschachthöhle, 1805 m a.s.I.) and the Grebenzen (SW Styria, Wildes Loch, $1800 \mathrm{~m}$ a.s.l. - Supplementary Table 1).

These finds of elk at and above the treeline are slightly higher than those reported from the Swiss Alps. While elk remains in the Swiss Prealps were found up to $1630 \mathrm{~m}$ a.s.l. at Schrattenfluh (Blant, 2004), a single find from Innerbergli north of Lake Thun was made at $1800 \mathrm{~m}$ a.s.l. (Morel, 1998, M. Blant, written comm. 2019). Morel (1998) attributed the presence of this forest-affine animal at these elevations to the presence of nutrient-rich plants, which are present well above $1000 \mathrm{~m}$ a.s.l. during late summer and early autumn. Elks probably spent late autumn to early summer down in the valleys. 


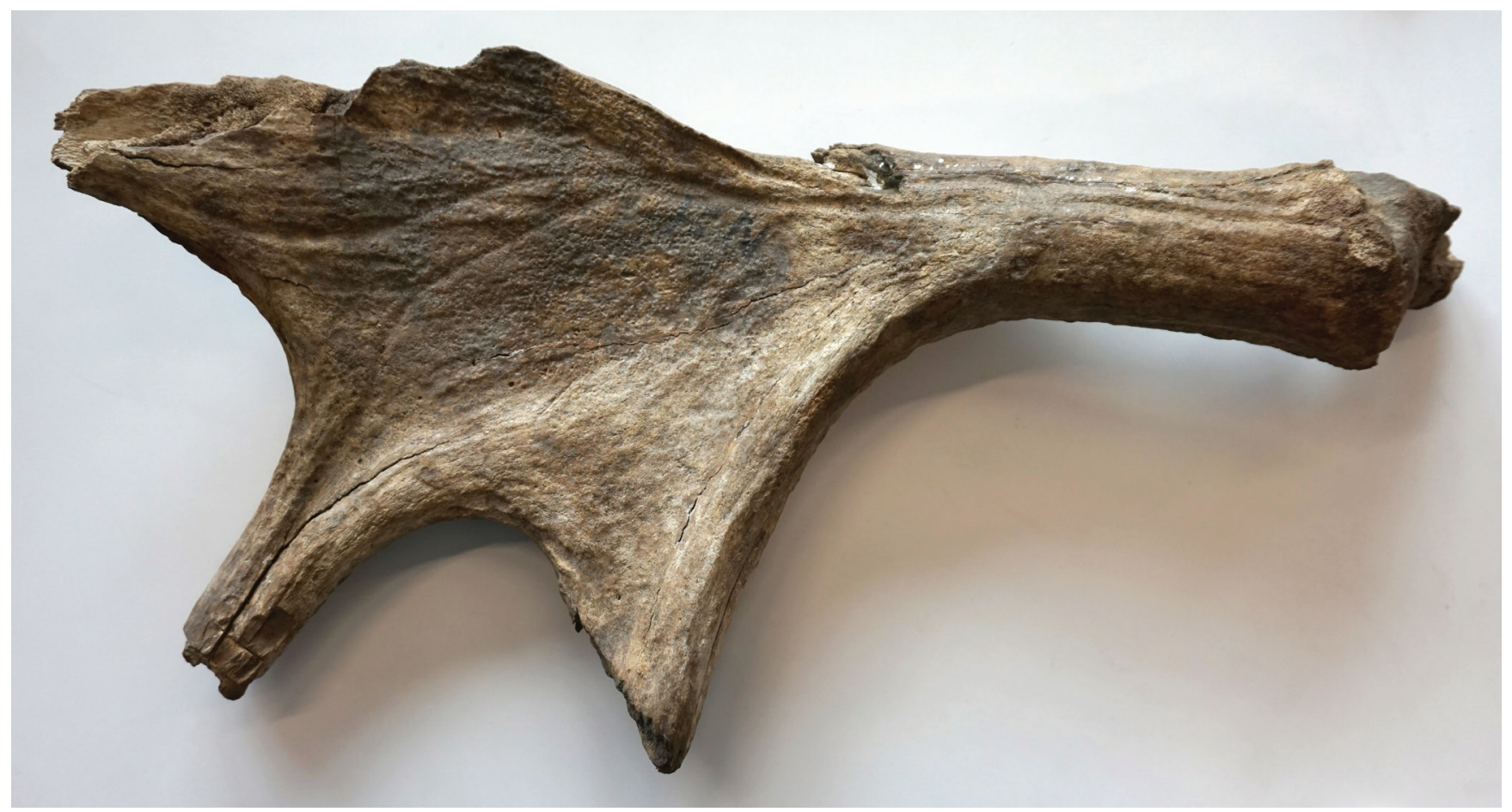

Fig. 5: Antler found in the inner Defereggen valley. Width of antler $47 \mathrm{~cm}$. Photo: C. Spötl

\subsection{Age distribution}

Unfortunately, radiocarbon dates of elk remains are available only for a small number (11\%) of the 107 sites in Austria. Still, their context - either archaeological finds or stratigraphic data - provide broad age constraints for $90 \%$ of these sites. Only $10 \%$ of the sites are of unknown age (Fig. 1). Among those sites with reasonably good age constraints there is a clear dominance of Holocene (72\%) over Pleistocene finds (18\%). We also made an attempt to subdivide Holocene finds into lower, middle and upper Holocene following Walker et al. (2019; Fig. 7). This was possible only for $48 \%$ of the Holocene sites given the lack of sufficient age constraints for slightly more than about half of these finds. Upper Holocene sites dominate (78\%), followed by middle (16\%) and lower Holocene (6\%). Although not statistically significant, this pattern is also seen in the few Holocene sites where radiocarbon analyses performed on elk remains are available: upper (7 samples), middle (3 samples), lower Holocene (no samples).

To summarise, the record of elk remains in Austria is strongly biased towards young finds. $72 \%$ are Holocene in age and among those $78 \%$ are younger than $4200 \mathrm{cal}$ BP (the boundary between middle and upper Holocene - Walker et al., 2019). These data are in good agreement with other studies, which show that elk remains are generally rare in the upper Pleistocene of Central Europe (Schmölcke and Zachos, 2005; Serangeli, 2006). Elks were certainly around in the Alps and their foreland prior to the onset of the Holocene, but their findings are much less abundant than e.g. those of Ursus spelaeus, Rangifer or Crocuta (Döppes and Rabeder, 1997). It is also interesting that none of the 107 sites dates from the Late Glacial, when elks were known e.g. in Central Europe (e.g.,
Serangeli, 2006; Schmölcke and Zachos, 2005; Fahlke, 2009), including southern Germany (Jochim et al., 2015: 113). We suppose that this reflects the small percentage of dated sites in Austria. The low density of elk remains of Lower Holocene age in Austria, however, is consistent with other studies, showing a conspicuous lack of elk fossils from Southern Germany for this time interval despite the presence of numerous karst pits e.g. on the Swabian Alb, which acted as animal traps (Fahlke, 2009: 117). The increasing density of elk remains in both southern Germany and Austria from the middle Holocene onward reflects a southward expansion of this animal possibly due to a successive opening of the initially dense forests as a result of clearing and farming (Schmölcke and Zachos, 2005).

The youngest radiocarbon-dated elk find in Austria is an antler from Gaflein Valley in central Tyrol (1285-1359 cal BP or 665-591 AD; Fig. 2). This age interval is similar to the youngest elk finds in the Swiss Alps: $1325-1538$ cal BP or 625-412 AD (1535 \pm 55 BP) at Innerbergli, Hohgant (Morel, 1998), $1401-1689 \mathrm{cal} B P$ or $549-261$ AD $(1630 \pm 50$ BP) at Elchlöchli, Schrattenfluh (Blant, 2004) and 1574-1713 cal BP or 376-237 AD (1748 $\pm 20 \mathrm{BP})$ at Chromatte, Habkern (Blant et al., 2019). It was concluded that the elk disappeared in Switzerland between the 5th and the 7th century AD, probably because of the shrinking of its habitat, possibly due to increased pressure from humans (Morel, 1998). The only exception are three elk remains from an archaeological site at Frohburg/Trimbach which were indirectly dated to the 13th and 14th century AD (Markert, 1989).

The data from Austria confirm that the elk survived beyond Roman times in the Alps and became extinct in most regions before the onset of the Middle Ages. The youngest isolated elk finds in Austria were reported from an 


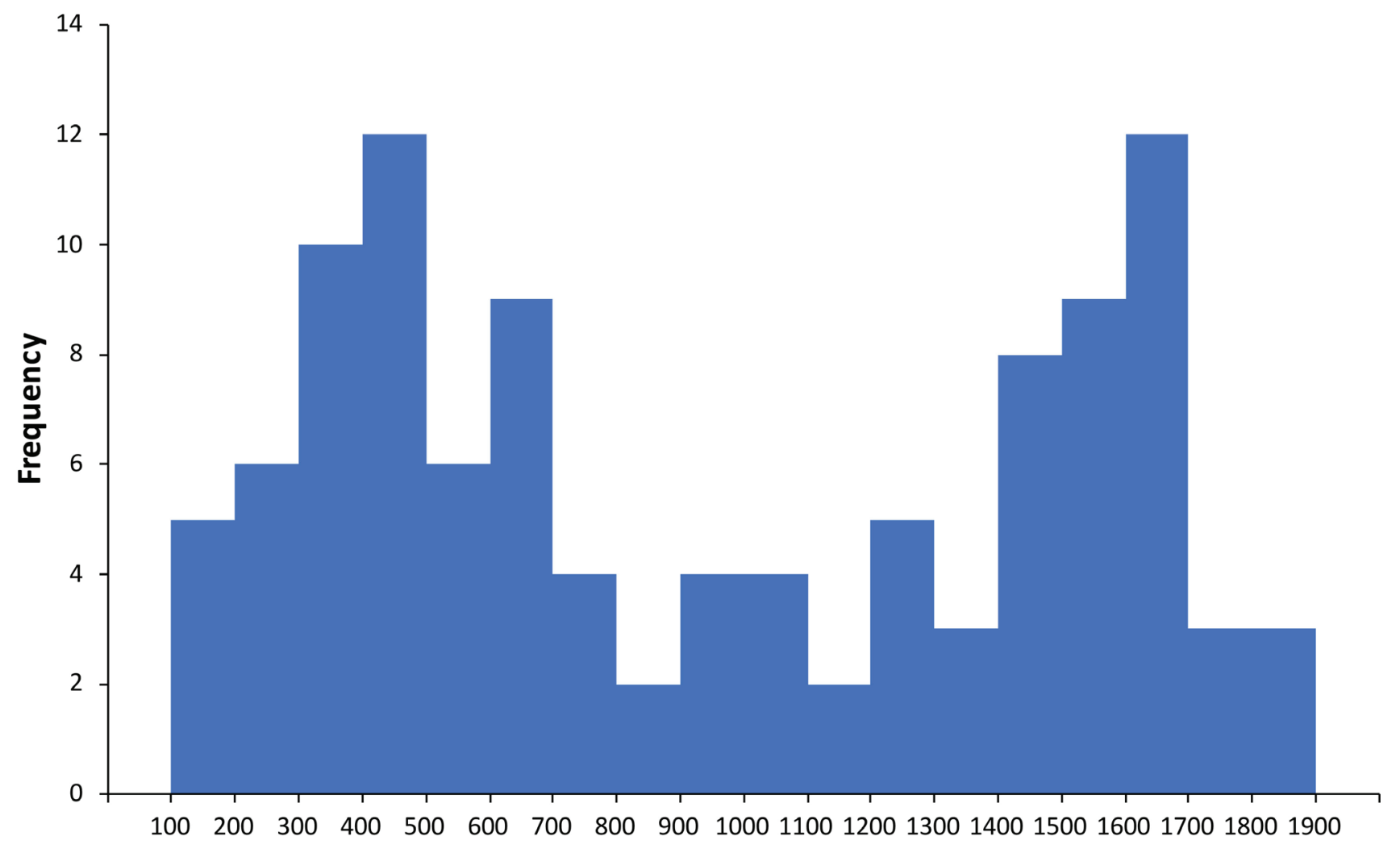

Altitude (m a.s.l.)

Fig. 6: Elevation distribution of Austrian elk finds.

excavated castle near Raabs an der Thaya (Pucher and Schmitzberger, 1999) and a burial ground in Thunau am Kamp (Kanelutti, 1990), both indirectly dated to the 10th century AD (Supplementary Table 1).

\section{Conclusions}

Based on a comprehensive effort to identify all elk remains ever found in Austria, which are spread over many museums and collections, we established a database of 107 sites, which allows to draw the following conclusions:

- The elk record is biased towards finds in the Northern Calcareous Alps where abundant caves acted as animal traps.

- Elk remains from the last glacial period are present locally but are not abundant.

- The apparent lack of elk remains from the Late Glacial may reflect the low number of available radiocarbon dates of this animal.

- $\quad 72 \%$ of all finds are Holocene in age, whereby upper Holocene finds dominate over those of middle and lower Holocene age.

- Our compilation, augmented by new radiocarbon dates from western Austria, show that elks were present up to and even above the treeline in the Austrian Alps and survived in diminishing populations almost until the onset of the Middle Ages.

\section{Appendix: The return of elks to Austria}

For about a millennium no elks were seen in Austria. Thanks to protection measures implemented in Russia in 1919, the shrinking elk populations stabilised in Russia and later also in Poland. Subsequently, a renewed southwestward migration towards Central and Western Europe started, with Germany being the western distribution limit. In recent decades the population size of elks in Northern and Eastern Europe reached values probably higher than ever before in the Holocene (Steiner, 1995). The margins of the recent distribution areas are characterised by oscillating migration into subarctic deciduous forests and forest steppes and by fluctuating biogeographical boundaries in the south and southwest (Nygrén 1986).

Starting from 1964 (Niederkappl im Mühlviertel) individual elks from two Czech populations reached also Austria again (Steiner, 1995). Published data (e.g., Steiner, 1995) and a database updated by T. Engleder (which records data of migrating animals, direct observations, dead animals, tracks, track droppings, bitten shrubs as well as film and photographic documents) reveal a strongly fluctuating presence of elks between 1964 and 2016 (Fig. 8), confined to the north(eastern) part of Austria. The elk statistics could be slightly influenced by potentially double-counting of migrating individuals between the Czech Republic and Austria as well as between the Mühlviertel and the Waldviertel. 

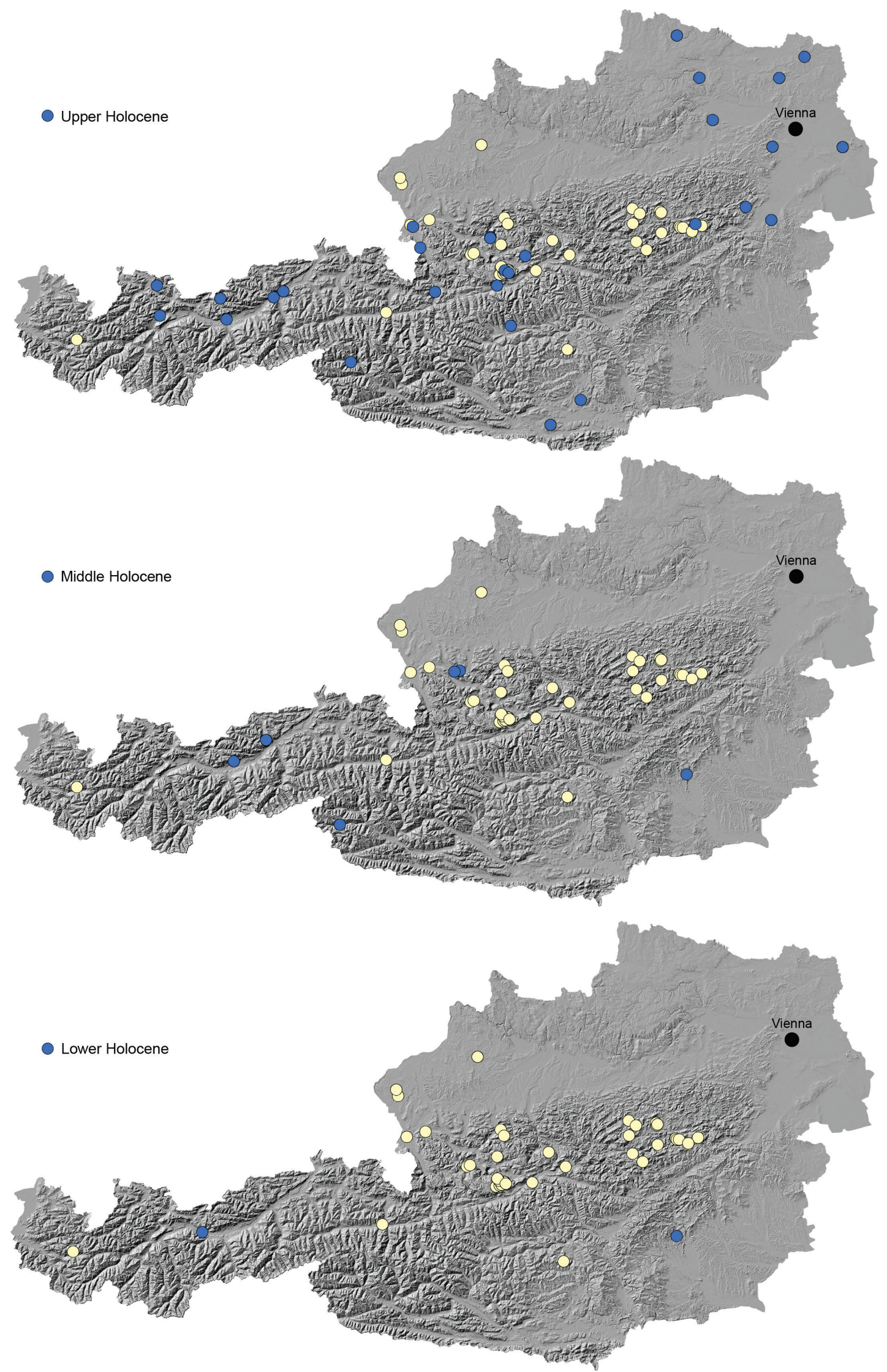

Fig. 7: Maps showing the distribution of lower, middle and upper Holocene elk remains in Austria. Yellow dots refer to Holocene sites where no subdivision is possible. 


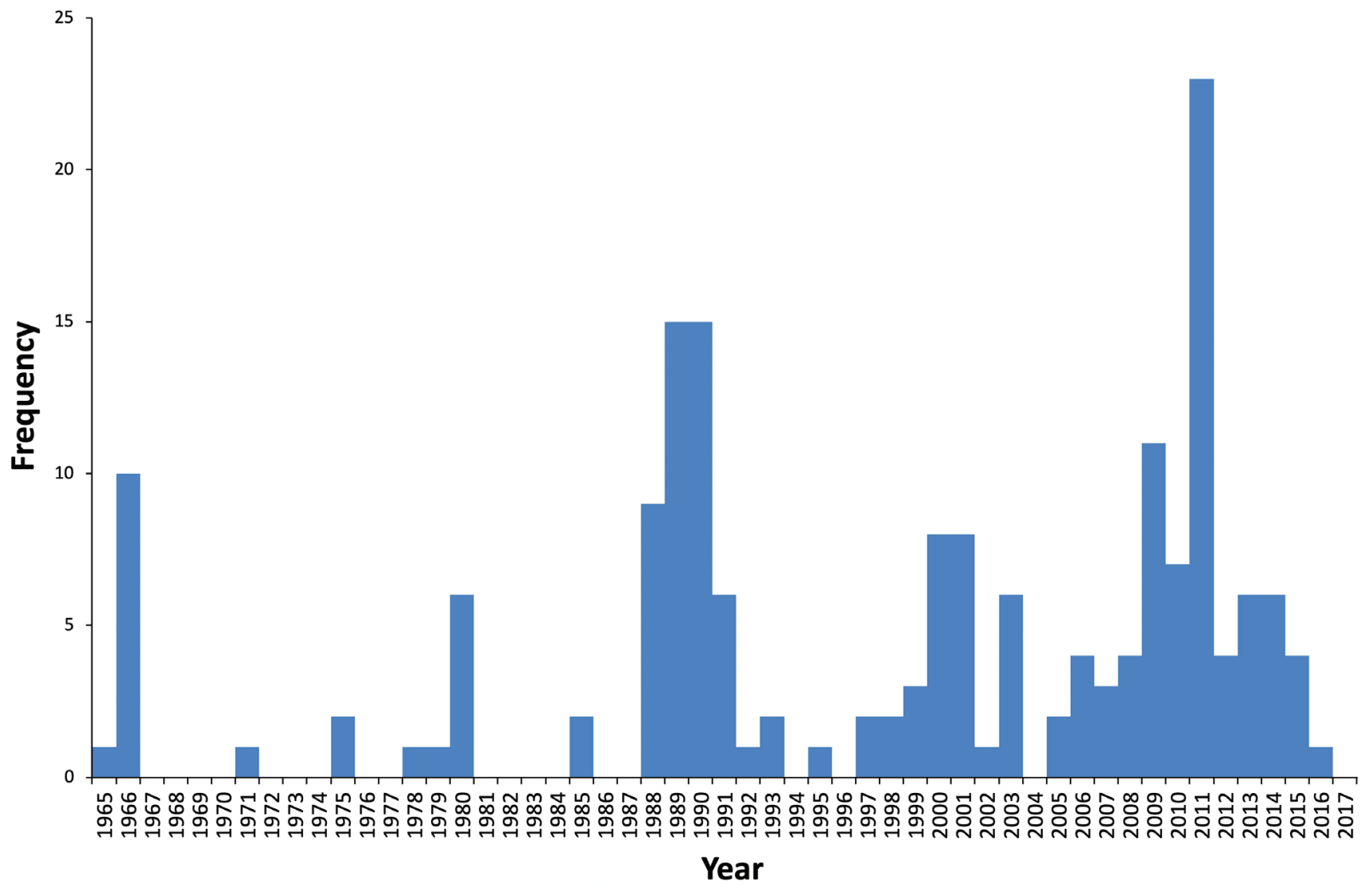

Fig. 8: Elk sightings per year in Austria since 1964.

Increased sightings of elks were made after the opening of the former "Iron Curtain". Starting with these migration waves, several attempts of younger elk individuals were registered to establish themselves as resident species in the north of the Austrian distribution area. Between 1964 and 2016, 20 adults with juveniles, respectively females with calves, were recorded, among them two females with two calves (June 1999 and December 2010). In 1999 it was observed how elks were attacked by a lynx. The elks in northern Austria are cross-border commuters, whereby the majority of them were born close to the border in the Czech Republic.

There is a relationship between the decline of the recent Austrian elk population and climate change, because frequent hot and dry summers reduce the quality of food. Long-term studies in Sweden have shown that the birth weight of the calves consequently decreases considerably and that numerous elks only have one calf, and many others have none at all.

The loss of three female elks in the Czech Republic due to accidents in recent years also had a major irreparable impact on this small population near the border. The outbreak of the bark beetle in 2015 and subsequent persistent disruptions caused by forestry also exert a negative influence on the small Austrian elk population (T. Engleder, pers. comm. 2020).

\section{Acknowledgements}

We are grateful for a number of colleagues who provided access to specimens and data for this study: B. Berning (OÖ Landesmuseum), M. Blant (ISSKA), S. Deschler-Erb (Basel). C. Dojen (Landesmuseum für Kärnten), S. Ebner and S. Weis (Museum Schloss Bruck), T. Engleder (Haslach/ Mühl), G. Friebe (Vorarlberger Landesmuseum), M. Gross (Joanneum), N. Lindner (Haus der Natur), M. Martys (Alpenzoo), L. Plan (Naturhistorisches Museum Wien), H. Pleninger (Gröbming), V. Reinprecht (Amt der Burgenländischen Landesregierung), M. Schaffhauser (Tiroler Landesmuseen), M. Riedl (Kapfenberg), E. Steiner (Museum Niederösterreich), U. Töchterle (Univ. Innsbruck). We thank P. Reimer (Belfast) for performing radiocarbon dating on a few samples, C. Tenreiter and G. Rabeder for kindly providing two radiocarbon dates from Hohe Schrott (funded by the OÖ Landesmuseum), H. Pomella for her help with the GIS software, and Kristof Veitschegger and Jérémy Tissier for comments on an earlier version of this article.

\section{References}

Aaris-Sørensen, K., 1992. Deglaciation chronology and re-immigration of large mammals. A South Scandinavian example from Late Weichselian-Early Flandrian. Courier Forschungsinstitut Senckenberg, 153, 143-149. 
Abrahamczik, W., 1935. Karsterscheinungen in der Umgebung von Lunz am See, mit besonderer Berücksichtigung der Höhlen. Unpublished PhD thesis, University of Vienna.

Aichhorn, S., Plankensteiner, A., 1875. Das wilde Loch auf der Grebenzen-Alpe und die darin aufgefundenen thierischen Ueberreste. Mitteilungen des Naturwissenschaftlichen Vereins für Steiermark, 12, 167-186.

Andrich, A., 1940. Zehn Jahre Höhlenforschung in Mariazell. Mitteilungen über Höhlen- und Karstforschung (Berlin), 1940/1, 11-19.

Anonymous, 1959. Elchschaufel bei Mürzzuschlag. Der Anblick, 14/7, 226.

Anonymous, 1954. Am Plansee waren Elche heimisch. Außerferner Nachrichten, 29, 17.7.1954.

Artner, W., Brandl, M., Christandl, G., Gutjahr, C., Obereder, J., Postl, W., Trausner, M., 2011. Die kupferzeitliche Höhensiedlung auf der "Kanzel“ bei Graz, Steiermark. Fundberichte aus Österreich, 50, 43-66.

Auer, A., 1974. Elchknochenfunde aus Höhlen und Schächten des Steirischen Salzkammergutes. Mitteilungen der Sektion Ausseerland des Landesvereines für Höhlenkunde in Steiermark, 12/3, 37-39.

Bachofen von Echt, R., Hoffer, W., 1930. Jagdgeschichte Steiermarks, vol. 3, Jagdstatistik und Geschichte des Steirischen Wildes. Graz (Leykam).

Bartosiewicz, L., 2005. Worked elk (Alces alces L. 1758) antler from Central Europe. In: Luik, H., Choyke, A.M., Batey, C.E., Lougas, L. (Eds.), From Hooves to Horns, from Mollusc to Mammoth - Manufacture and Use of Bone Artefacts from Prehistoric Times to the Present. Proceedings of the 4th Meeting of the ICAZ Worked Bone Research Group at Tallinn, 339-350.

Bauer, K., 1978. Holozäne Säugetierfunde im Höhlengebiet von Hirscheck und Traweng (Tauplitzalm, Steiermark). Die Höhle, 29, 57-61.

Bauer, K., Spitzenberger, F., 2001. Elch Alces alces (Linnaeus, 1758). In: Spitzenberger, F. (ed.), Die Säugetierfauna Österreichs. Grüne Reihe des Bundesministeriums für Land- und Forstwirtschaft, Umwelt und Wasserwirtschaft, 13, 713-720.

Bauer, K. Spitzenberger, F., 1970. Die Tierknochen aus dem neolithischen Hornsteinbergwerk von Mauer bei Wien. Mitteilungen der Anthropologischen Gesellschaft in Wien, 100, 111-115.

Bauer, K., Wolff, P., 1985. Faunistische Untersuchungen am ausgegrabenen Knochenmaterial von Pitten, Niederösterreich. Mitteilungen der Prähistorischen Kommission der Akademie der Wissenschaften Wien, 21-22, 13-21.

Bayerl, F., Friedl, K., Friedl, I., Lenger, A., 2001. Alpenregion Hochschwab. 2nd edition, Verlag G. Höller.

Blant, M., 2004. Die holozäne Fauna der Schrattenfluh. Stalactite, 54, 17-26.

Blant, M., Häuselmann, P., Müller, W., 2019. Nouvelle découverte d'élans dans la région d'Habkern (Préalpes bernoises) et synthèse des connaissances. Akten des 14. Nationalen Kongresses für Höhlenforschung, Sinterlaken 2019, 145-148.
Chaix, L., Desse, J., 1981. Contribution à la connaissance de l'élan (Alces alces, L.) postglaciaire du Jura et du Plateau suisse. Quartär 31/32, 139-190.

Czeika, S., 2000. Tierreste aus einer spätrömischen Rückzugssiedlung in der Gemeinde Ramsau am Dachstein, Steiermark. Mitteilungen der ANISA, 21, 11-14.

Dimitz, 1879. Elchfunde im Salzkammergut. Hugos Jagdzeitung, 22/18, 505-507.

Dolenz, H., Weiss, E.H., 1960. Die Kulturschichten unter dem Höhlendach der oberen Vorhöhle; Schnitt 1959. Carinthia II, 150/70, 13-19.

Döppes, D., 2018. Die Gassel-Tropfsteinhöhle - eine Bärenhöhle. In: Mattes, J., Kuffner, D. (Eds.), Höh(I)enluft und Wissensraum. Die Gassel-Tropfsteinhöhle im Salzkammergut zwischen Alltagskultur, Naturkunde und wissenschaftlicher Forschung. Denisia 40, 305-316.

Döppes, D., Rabeder, G., 1997. Pliozäne und pleistozäne Faunen Österreichs. Mitteilungen der Kommission für Quartärforschung an der Österreichischen Akademie der Wissenschaften, 10, 1-411.

Ehrenberg, K., 1962. Bemerkungen über die Bestände an Höhlenfunden im Oberösterreichischen Landesmuseum. Jahrbuch des Oberösterreichischen Musealvereines, 107, 394-437.

Ehrenberg, K., 1970. Über Fundbesichtigungen und Höhlenbefahrungen im steirischen Salzkammergut. Die Höhle, 21, 39-43.

Engelbrecht, O., 1952. Höhlenforschungen im Karwendelgebirge. Die Höhle, 3, 15.

Fahlke, J.M., 2009. Der Austausch der terrestrischen Säugetierfauna an der Pleistozän/Holozän-Grenze in Mitteleuropa. Unpublished PhD thesis, University of Bonn. http://hss.ulb.uni-bonn.de/2009/1836/1836.pdf

Felgenhauer, F., 1964. Ein verziertes Elchgeweihbruchstück aus Carnuntum. Archaeologia Austriaca, 35, 119122.

Fink, M.H., Hartmann, H., Hartmann, W., 1979. Die Höhlen Niederösterreichs. Vol. 1. Wissenschaftliche Beihefte zur Zeitschrift die Höhle, 28, Vienna (Landesverein für Höhlenkunde Wien und Niederösterreich).

Fliri, F., 1971. Beiträge zur Stratigraphie und Chronologie der Inntalterrasse im Raum von Innsbruck. Veröffentlichungen des Museums Ferdinandeum, 51, 5-21.

Friedl, K., Gross, M., 2004. Elche am Hochschwab. Reibeisen, 21, 171-172.

Fruth, M., 1966. Tierknochenfunde aus der Stadt am Magdalensberg bei Klagenfurt in Kärnten. IV. Die Wiederkäuer ohne die Bovini. Kärntner Museumsschriften, 41, 6-127.

Galik, A., 1997. Die Ungulata aus der Schusterlucke im Kremstal (Waldviertel, Niederösterreich). Wissenschaftliche Mitteilungen des Niederösterreichischen Landesmuseums, 10, 83-103.

Gams, H., 1947. Das Ibmer Moos. Erster Bericht über die im Auftrage des Linzer Landesmuseums durchgeführten Untersuchungen. Jahrbuch des Oberösterreichischen Musealvereins, 92, 289-338. 
Geilhofer, R., 1926. Das Spullersee-Kraftwerk. Schriften des Vereins für Geschichte des Bodensees und seiner Umgebung, 53 (1924), 123-174.

Gleirscher, P., Pacher, M., 2005. Griffen und die Altsteinzeit im Südostalpenraum. Rudolfinum. Jahrbuch des Landesmuseums Kärnten, 2004, 65-107.

Gostenčnik, K., 2003. Ein neuer Elchgeweihfund vom Magdalensberg. Carinthia I 193, 131-139.

Graf, G., 2014. Elchfunde im Kammergebirge (Dachstein). Schriftenreihe des Kammerhofmuseums Bad Aussee, $32,1-18$.

Gruber, H., 2013. Betreuung und Sicherung von archäologischen Denkmalen im Berichtsjahr. Berichte aus den Bundesländern. Oberösterreich, 18-20.

Gwessler, F., 1979. Die Elchknochenfunde im Schartenschacht (östl. Dachsteinmassiv). Mitteilungen der Sektion Ausseerland des Landesvereines für Höhlenkunde in Steiermark, 17/1, 3-16.

Hamann, H.H.F., 1960. Der Mönchgraben vor dem Bau der Autobahn. Naturkundliches Jahrbuch der Stadt Linz, 1960, 113-244.

Hartmann, H., Hartmann, W., 1982. Die Höhlen Niederösterreichs. Vol. 2. Wissenschaftliche Beihefte zur Zeitschrift die Höhle, 29, Vienna (Landesverein für Höhlenkunde Wien und Niederösterreich).

Hartmann, H., Hartmann, W., 1985. Die Höhlen Niederösterreichs. Vol. 3., Wissenschaftliche Beihefte zur Zeitschrift die Höhle, 30, Vienna (Landesverein für Höhlenkunde Wien und Niederösterreich).

Hartmann, H., Hartmann, W., 1990. Die Höhlen Niederösterreichs. Vol. 4. Wissenschaftliche Beihefte zur Zeitschrift die Höhle, 37, Vienna (Landesverein für Höhlenkunde Wien und Niederösterreich).

Heißel, W., 1954. Beiträge zur Quartärgeologie des Inntales. Jahrbuch der Geologischen Bundesanstalt, 98, 252-322.

Hell, M., 1936a. Ein Elchgeweih aus Salzburg. Salzburger Volksblatt, 30.5.1936.

Hell, M., 1936b. Der Elch in Salzburg. Salzburger Chronik, 16.6.1936

Hell, M., Koblitz, H., 1918. Die prähistorischen Funde vom Rainberge in Salzburg. Österreichische Kunsttopographie, 17, 1-37.

Herrmann, E., Pucher, E., Nicolussi, K., 2011. Das Schneeloch auf der Hinteralm (Schneealpe, Steiermark): Speläomorphologie, Eisveränderung, Paläozoologie und Dendrochronologie. Die Höhle, 61, 57-72.

Hoffer, W., 1933. Zoogeographische Studien am jagdbaren Wilde Steiermarks. Mitteilungen des Naturwissenschaftlichen Vereins Steiermark, 68, 51-82.

Hofmann, E., Kirnbauer, F., 1935. Diluviale Funde aus der Kaolingrube Kriechbaum bei Schwertberg. Oberösterreich. Berg- und Hüttenmännisches Jahrbuch, 83, 28-34.

Hornberger, M., 1970. Gesamtbeurteilung der Tierknochenfunde aus der Stadt auf dem Magdalensberg in Kärnten (1948-1966). Naturkundliche Forschungen zu den Grabungen auf dem Magdalensberg 10, Kärntner Museumsschriften, 49, 1-144.
Huijsmans, M., Krauß, R., 2015. 6.000 Jahre Brixlegg. Fundberichte aus Österreich, Materialheft A, 22, 1-379.

Jäger G., 2002. Spuren eines ehemaligen Alpenbewohners entdeckt. Tiroler Tageszeitung, 31, 6.2.2002.

Jochim, M.A., Kind, C.-J., Kleinmann, A., Merkt, J., Stephan, E., 2015. Eine spätpaläolithische Fundstelle am Ufer des Federsees: Bad Buchau-Kappel, Flurstück Gemeindebeunden. Fundberichte aus Baden-Württemberg, 35, 37-134.

Kanelutti, E., 1990. Slawen- und urnenfelderzeitliche Säugetiere von Thunau bei Gars am Kamp (Niederösterreich). Unpublished PhD thesis University of Vienna.

Karning, K., 1936. Leonding. Fundberichte aus Österreich, 2 (1936), 94.

Kerschner, T., 1930. 3. Bericht uber die naturwissenschaftlichen Abteilungen. Jahrbuch des Oberösterreichischen Musealvereins, 83, 26-39.

Kerschner, T., Schadler, J., 1933. Geschichte der naturwissenschaftlichen Sammlungen des oberösterreichischen Landesmuseums. Jahrbuch des Oberösterreichischen Musealvereins, 85, 345-479.

Kloiber, Ä., Stroh, F., 1959. St. Florian am Inn. Fundberichte aus Österreich, 5 (1946-1950), 57.

Kohl, H., 1999. Das Eiszeitalter in Oberösterreich. Vol. 3. Jahrbuch des Oberösterreichischen Musealvereins, 144/1, 249-429.

Kollreider, F., 1953. St. Leonhard in Defreggen eine uralte Siedlung. Osttiroler Heimatblätter, 21/3, 7-8.

Lebzelter, V., 1933. Die hallstattzeitliche Siedlung auf dem Steinberge bei Ernstbrunn. Mitteilungen Anthropologische Gesellschaft in Wien, 63, 108-125.

Leichter, P., Pfarr, T., 1975. Elchhöhle (1623/31). Mitteilungen der Sektion Ausseerland des Landesvereines für Höhlenkunde in Steiermark, 13/3, 26-29.

Markert, D., 1989. Die Tierknochen. In: Meyer, W. (Ed.), Die Frohburg. Ausgrabungen 1973-1977. Schweizer Beiträge zur Kulturgeschichte und Archäologie des Mittelalters, 16.

Mayr, F., 1968. Über den Beginn der Würmeiszeit im Inntal bei Innsbruck. Eine paläogeographische Skizze. Zeitschrift für Geomorphologie Neue Folge 112: 256-295.

Morel, P., 1998. Les os d'élans Alces alces (L. 1758) holocènes du gouffre 1 des Grand Bois (Jura neuchâtelois, Les Verrières NE): nouvelle datation radiocarbone et brève mise au point des connaissances actuelles. Bulletin de la Société Neuchâteloise des Sciences Naturelles, 121, 45-52.

Moser, E.K., 1970. Vorgeschichtliche Siedlungs- und Fundtopographie von Innsbruck-Hötting. Mitteilungen Anthropologische Gesellschaft in Wien, 100, 194-206.

Moser, E.K., 1967. Vor- und frühgeschichtliche Siedlungsund Fundtopographie von Innsbruck-Hötting. Unpublished PhD thesis University of Innsbruck.

Mühlhöfer, F., 1938. Grünbach am Schneeberge. Fundberichte aus Österreich, 2, 244.

Mühlhöfer, F., 1937. Grünbach am Schneeberg. Fundberichte aus Österreich, 2, 144. 
Murban, K., Mottl, M., 1953. Eiszeitforschungen des Joanneums in Höhlen der Steiermark. Mitteilungen des Museums für Bergbau, Geologie und Technik am Landesmuseum „Joanneum", Graz, 11, 1-58.

Mutschlechner, G., 1959. Fund eines Elch-Skeletts im westlichen Karwendel. Die Pyramide, 7, 76-79.

Nicolussi, K., Kaufmann, M., Patzelt, G., van der Plicht, J., Thurner, A., 2005. Holocene tree-line variability in the Kauner Valley, central Eastern Alps, indicated by dendrochronological analysis of living trees and subfossil logs. Vegetation History and Archaeobotany, 14, 221234. doi: 10.1007/s00334-005-0013-y

Niederwolfsgruber, F., 1962. Elch-Skelett als Naturdenkmal. Natur und Land, 1962/1, 18-19.

Nygrén, K.F., 1986. Alces alces - Elch. In: Niethammer, J., Krapp, F. (Eds.), Handbuch der Säugetiere Europas. Vol. 2/II. Paarhufer - Artiodactyla (Suidae, Cervidae, Bovidae). AULA-Verlag, Wiesbaden, 173-197.

Offenberger, J., 1983. Der Pfahlbau im Keutschachersee in Kärnten. Fundberichte aus Österreich, 21 (1982), 133141.

Paschinger, H., 1950. Beobachtungen an den Bändertonlagern von Inzing bei Innsbruck. Schlern-Schriften, 65, 55-61.

Pietersteiner, K., Spötl, C., 2011. Neuvermessung der Vorderkarhöhle bei Scharnitz. Höhlenkundliche Mitteilungen des Landesvereins für Höhlenkunde in Tirol, 49, 9-14.

Plan, L., Oberender, P., 2016. Höhlen in Österreich. In: Spötl, C., Plan, L., Christian, E. (Eds.), Höhlen und Karst in Österreich. Oberösterreichiches Landesmuseum, Linz, 11-22.

Pucher, E., 1999. Archäozoologische Untersuchungen am Tierknochenmaterial der keltischen Gewerbesiedlung im Ramsautal auf dem Dürrnberg (Salzburg). Dürrnberg-Forschungen, 2, 1-129.

Pucher, E., 1986. Bronzezeitliche Tierknochen vom Buchberg, OG Wiesing, Tirol. Fundberichte aus Österreich, 23 (1984), 209-220.

Pucher, E., 1982. Tierknochenfunde aus Stillried an der March (Niederösterreich). Unpublished PhD thesis University of Vienna.

Pucher, E., Schmitzberger, M., 1999. Ein mittelalterlicher Fundkomplex aus Niederösterreich mit hohem Wildanteil: Die Flur Sand bei Raabs a.d. Thaya. In: Becker, C., Manhart, H., Peters, J., Schibler, J. (Eds.), Historia animalium ex ossibus. Festschrift für Angela von den Driesch. Marie Leidorf, Rahden/Westfalen, 355-378.

Rebel, H., 1933. Die freilebenden Säugetiere Österreichs als Prodromus einer heimischen Mammalienfauna. Vienna (Österreichischer Bundesverlag für Unterricht, Wissenschaft, Kunst).

Ressl, F., 1980. Naturkunde des Bezirkes Scheibbs. Die Tierwelt des Bezirkes Scheibbs. Erster Teil: Faunistische Arbeitsgrundlagen und ihre Auswertung. Scheibbs (Naturkundliche Arbeitsgemeinschaft des Bezirkes Scheibbs).
Rosvold, J., Andersen, R., Linnell, J.D.C., Hufthammer, A.K., 2013. Cervids in a dynamic northern landscape: Holocene changes in the relative abundance of moose and red deer at the limits of their distributions. The Holocene, 23, 1143-1150. doi: 10.1177/0959683613483625

Schmidt, E.O., 1859. Das Elen mit dem Hirsch und dem Höhlenbären fossil auf der Grebenzer Alpe in Obersteier. Sitzungsberichte der Akademie der Wissenschaften mathematisch-naturwissenschaftliche Klasse, 37, 249256.

Schmitzberger, M., 2012. Die Tierknochen vom Ramsaukopf, Putzenkopf und Putzenfeld - neue Funde vom keltischen Dürrnberg bei Hallein. Annalen des Naturhistorischen Museums Wien, Serie A, 114, 79-138.

Schmölcke, U., Zachos, F.E., 2005. Holocene distribution and extinction of the moose (Alces alces, Cervidae) in Central Europe. Mammalian Biology, 70, 329-344. doi:10.1016/j.mambio.2005.08.001

Serangeli, J., 2006. Verbreitung der großen Jagdfauna in Mittel- und Westeuropa im oberen Jungpleistozän. Ein kritischer Beitrag. Tübinger Arbeiten zur Urgeschichte, 3, 1-255.

Spötl, C., Reimer, P.J., Starnberger, R., Reimer, R., 2013. A new radiocarbon chronology of Baumkirchen, stratotype for the onset of the Upper Würmian in the Alps. Journal of Quaternary Science, 28, 552-558. doi. org/10.1002/jqs.2645

Steiner, E.. 1995. Die Rückkehr des Elches (Alces alces L.) nach Österreich - eine Chronologie der Ereignisse. Stapfia, 37, 255-267.

Stüber, E., Lindner, R., Jerabek, M., 2014. Die Säugetiere Salzburgs. Salzburger Natur-Monographien 2, Verlag Haus der Natur.

Szombathy, J., 1888. Fundstücke aus Gräbern bei KleinHadersdorf nächst Poisdorf in Niederösterreich. Mitteilungen der Anthropologischen Gesellschaft Wien, 18, 14-16.

Teller, F., 1880. Ueber einen neuen Fund von Cervus alces in den Alpen. Verhandlungen der k.k. Geologischen Reichsanstalt, 1880, 69-77.

Tenreiter, C., 2014. Die Höhlen südlich des Ramaikögerls in der Hohen Schrott (1616, OÖ). Die Höhle, 65, 63-72.

Thenius, E., 1959. Die jungpleistozäne Wirbeltierfauna von Willendorf i. d. Wachau, N.Ö. Mitteilungen der Prähistorischen Kommission, 8/9, 133-170.

Tichy, G., 1986. Die ersten Funde von Bison und Elch aus dem Postglazial Salzburgs. Der Karinthin, 94, 365-379.

Töchterle, U., 2015. Der Kiechlberg bei Thaur als Drehscheibe zwischen den Kulturen nördlich und südlich des Alpenhauptkammes. Ein Beitrag zum Spätneolithikum und zur Früh- und Mittelbronzezeit in Nordtirol. Universitätsforschungen zur prähistorischen Archäologie, 261, 1-669, Verlag Habelt, Bonn.

Tratz, E.P., 1931. Auf Elche in den steirischen Alpen. Österreichisches Weidwerk, 22, 591-593.

Trimmel, H., 1989. Blaubruchhöhle und Wildes Loch zwei neue Naturdenkmale der Steiermark. Die Höhle, $40,85-86$. 
Veitschegger, C., 2013. Die Großsäuger aus Lindabrunn, Niederösterreich (Frühholozän). Unpublished Master thesis University of Vienna.

Velthuysen, H., 1961. Die Elchschaufel von Osttirol. Der Anblick, 16/7, 209-210.

Waldner, F., 1946. Der Elch, eine verschwundene Wildgestalt unserer Heimat. Spelaelogische Mitteilungen, 1/1, 17-19. Walker, M., Head, M.J., Lowe, J., Berkelhammer, M., Björck, S., Cheng, H., Cwynar, L., Fisher, D., Gkinis, V., Long, A., Newnham, R., Rasmussen, S., Weiss, H., 2019. Subdividing the Holocene Series/Epoch: formalization of stages/ages and subseries/subepochs, and designation of GSSPs and auxiliary stratotypes. Journal of Quaternary Science, 34, 1-14. doi: 10.1002/jqs.3097

Willms, C., 1987. Der Elch im nacheiszeitlichen Europa. Archeologia Polski, 32, 249-291.

Wolff, P., 1977. Die Jagd- und Haustierfauna der spätneolithischen Pfahlbauten des Mondsees. Jahrbuch des Oberösterreichischen Museal-Vereins, 122/1, 269-347.

Received: 16.3 .2020

Accepted: 18.05.2020

Editorial handling: Björn Berning 